University of Nebraska - Lincoln

DigitalCommons@University of Nebraska - Lincoln

Educational Psychology Papers and

Publications

Educational Psychology, Department of

2008

\title{
Addressing Research Gaps in the Intersection between Homophobia and Bullying
}

Dorothy L. Espelage

University of Illinois at Urbana-Champaign, espelage@uiuc.edu

Susan M. Swearer Napolitano

University of Nebraska-Lincoln, sswearernapolitano1@unl.edu

Follow this and additional works at: https://digitalcommons.unl.edu/edpsychpapers

Part of the Educational Psychology Commons

Espelage, Dorothy L. and Swearer Napolitano, Susan M., "Addressing Research Gaps in the Intersection between Homophobia and Bullying" (2008). Educational Psychology Papers and Publications. 152.

https://digitalcommons.unl.edu/edpsychpapers/152

This Article is brought to you for free and open access by the Educational Psychology, Department of at DigitalCommons@University of Nebraska - Lincoln. It has been accepted for inclusion in Educational Psychology Papers and Publications by an authorized administrator of DigitalCommons@University of Nebraska - Lincoln. 


\title{
Addressing Research Gaps in the Intersection Between Homophobia and Bullying
}

\author{
Dorothy L. Espelage \\ University of Illinois at Urbana-Champaign \\ Susan M. Swearer \\ University of Nebraska-Lincoln
}

\begin{abstract}
Bullying, aggression, and peer victimization among adolescents are significant public health concerns. Recent research has demonstrated that bullying and peer victimization sometimes include homophobic epithets directed at heterosexual and lesbian, gay, bisexual, and transgender (LGBT) youth. It appears that being at the receiving end of homophobic banter generally contributes to worse outcomes among youth. This article highlights methodological issues in conducting research with LGBT youth, and stresses the importance of using theoretically and empirically supported definitions, including youth who are sexually questioning, focusing on multiple social and cultural contexts, and examining how support networks serve as buffering agents with regard to the effect of homophobic bullying on psychological outcomes.
\end{abstract}

Despite the links between bullying and homophobia, there has been little effort to integrate these areas of study. Findings focused on these topics highlight the prevalence and serious consequences of each area within the education system (Espelage \& Swearer, 2003; Kosciw, 2004; Rivers, 2001; Stein, 1995). Broadly conceived, aggression includes behaviors such as fighting, name-calling, bullying, and social exclusion (Crick, 1996, Espelage, Bosworth, \& Simon, 2000). Indicators of homophobia include negative attitudes, beliefs, behaviors, and stereotypes toward individuals who are not exclusively heterosexual (referred to as LGBT-lesbian, gay, bisexual, and transgendered individuals; Wright, Ad- ams, \& Bernat, 1999). Research suggests that victimization as a result of homophobia is not necessarily limited to LGBT-identified individuals, but can create a hostile climate for all students as it is a way in which masculine/ feminine gender-role norms are promoted and maintained (Epstein, 2001). Some 20 years ago in the book Homophobia: A Weapon of Sexism, written by the founder of the Women's Project in Arkansas, Suzanne Pharr (1988), it was recognized that homophobia marginalizes and oppresses LGBT individuals, especially women. Pharr, in her chapter on eliminating homophobia, argued that prevention has to be at multiple levels, and pointed to the importance of eliminating the tendency for

Correspondence regarding this article should be addressed to Dorothy L. Espelage, Department of Educational Psychology, University of Illinois, Urbana-Champaign, 220A Education Building, 1310 South 6th Street, Champaign, IL 61820; E-mail: espelage@uiuc.edu 
adults to overlook children and adolescents calling others derogatory names (i.e., "faggot").

More recent qualitative and ethnographic investigations have expanded on the importance of changing the language children and adolescents use, improving school environments that promote homophobic attitudes and behaviors, and protecting sexually questioning and LGBT youth (Kimmel \& Mahler, 2003; Phoenix, Frosh, \& Pattman, 2003; Plummer, 2001). These studies, coupled with recent quantitative studies (Poteat $\&$ Espelage, 2005; Poteat, Espelage, \& Green, 2007), have found strong associations among bullying, sexual orientation, and homophobia, and all of these have been related to negative school environments and over time related to negative psychological outcomes for students.

This special series includes four databased investigations that explore the relation among sexual orientation, homophobia, and bullying along with other mental health issues among middle and high school students. From these articles we work to frame the concept of homophobia within the context of current bullying research. By doing so, we seek to further examine ways in which homophobia perpetuates and defines forms of bullying and aggression. Several outcome variables are included in this research and underscore the serious nature of these social problems among adolescents. The research we present is quantitative in nature, and expands upon and clarifies prior qualitative findings. Collectively, our findings support the argument that homophobia and bullying should be examined concurrently in future research, and that discussion of homophobia should be included in bullying intervention programs within schools. We also offer additional suggestions for addressing and decreasing bullying and homophobia among students, and ideas for future research in this area.

We have ordered the articles with the intention of building complexity in the thinking on these topics. First, Swearer, Turner, Givens, and Pollack (2008) present findings on the relation between bullying and teasing and the use of homophobic epithets such as
"You are so gay" and how these comments are linked to negative psychological consequences among boys in an all-male school. Rivers and Noret (2008) extend our understanding of psychological adjustment among both heterosexual and LGBT male and female youth in the United Kingdom. Expanding the theoretical perspective of these behaviors to include peer group influences is the topic of the third article (Poteat, 2008). Then, the final article includes an examination of both contextual effects (school, parents) and psychological adjustment (Espelage, Aragon, Birkett, \& Koenig, 2008). This article demonstrates that the intersection and effect of bullying and homophobic attitudes on adjustment varies across social contexts. That is, outcomes depend on the support systems that youth have in their environment.

This special issue represents significant progress in starting to merge two research agendas on the psychological and sociological aspects of all children and adolescents who grow up in our schools. Our schools are not generally tolerant of any sexual orientation that varies from a heterosexual orientation. The set of four articles in the special series will push this research agenda to an exciting and intriguing level. It is our hope that these articles will pave the way for even more research on this subject. These articles represent groundbreaking methodological approaches and tackle many issues. Rather than reiterating the topic of each article, we will attempt to highlight the areas in which these articles push the integrations of these fields forward.

\section{Samples and Definitions Are Diverse}

In the four articles, sample characteristics and definitional issues vary. Swearer et al. (2008) include a study of an all-male college preparatory school, a sample that is often overlooked in psychological and sociological studies on homophobia and bullying alike. Poteat (2008) includes a sample of students from a high-achieving high school in Central Illinois, with a sample consisting of $25 \%$ Asian American students. Espelage et al. (2008) added to the extant literature by exam- 
ining a large sample of high school students across a number of schools with a wide range of socioeconomic and racial compositions, and Rivers and Noret (2008) included an international sample. These articles also include samples of general student populations who did not identify their sexual orientation (Swearer et al., 2008; Poteat, 2008); student populations who identified as heterosexual, homosexual, or sexually questioning (Espelage et al., 2008); and students who identified whether they were solely attracted to same-sex or opposite-sex youth (Rivers \& Noret, 2008). Espelage et al.'s (2008) categorization of youth as sexually questioning represents an important step in the research in that these youth reported more psychological distress than students who identified as either homosexual or heterosexual. These findings suggest that future studies need to consider how to ask survey questions to capture the potentially unique psychological and sociological aspects of being in a questioning phase of sexual orientation development.

\section{Homophobia and General Peer Victimization Coexist}

Homophobic attitudes and behaviors appear to be interrelated with other forms of verbal and physical forms of peer victimization. Swearer et al. (2008) demonstrated that $26 \%$ of boys (ninth through eleventh grades) who were bullied indicated that they were bullied by being called gay. This subsample of boys also reported the highest levels of verbal and physical bullying victimization. Poteat (2008) demonstrated that peer groups that are high on general aggression perpetration also have the highest levels of negative attitudes toward LGBT youth and greater use of homophobic epithets. Espelage et al. (2008) found that students who were sexually questioning and those who identified as homosexual reported being teased about their sexual orientation in comparison to heterosexual individuals. Rivers and Noret (2008) did not find differences in bullying victimization, perpetration, or observing bullying between youth attracted to same-sex youth and those who were attracted to opposite-sex youth, but they found that those attracted to same-sex peers worried more about being gay or lesbian. These findings suggest that homophobic attitudes and behaviors often coexist with other forms of aggression and victimization, which will require much more attention to measurement issues.

\section{Environment Matters}

Studies in this series support previous findings that experiencing homophobic banter is related to heightened psychological distress for the general student population (Swearer et al., 2008) and for sexual questioning youth (Espelage et al., 2008) and homosexual youth (Rivers \& Noret, 2008), and greater drug/alcohol use was found for youth questioning or those attracted to their same-sex peers (Espelage et al., 2008; Rivers \& Noret, 2008). However, these studies move beyond group differences to explicate potential buffering or exacerbating effects of the environment. In an online study of 3,450 public and private or parochial U.S. students (ages 13-18), 88\% of the students said that homophobic remarks were used at least some times when teachers were present, and many students reported that teachers and staff did not intervene during these incidents (Harris Interactive \& the Gay, Lesbian, and Straight Education Network [GLSEN], 2005). These findings suggest that the response of other students as well as teachers to homophobic banter might play an important role in developing and maintaining a climate that is not supportive of sexually questioning and LGBT youth. Indeed, Swearer et al. (2008) found an association between being bullied by being called gay and perceiving the school climate as negative. Students attracted to same-sex peers in Rivers and Noret's (2008) study did report seeking support from staff. Furthermore, Espelage et al. (2008) found a moderating effect for positive school climate and parental support for LGB and questioning students; more specifically, students who were questioning or LGB reported fewer negative psychological outcomes if they were in a school that they perceived to be 
positive or felt they had strong parental support. Poteat (2008) investigated perhaps the most instrumental context during early adolescence-peer groups. Using social network analysis to assess friendship groups and hierarchical linear modeling to study socialization effects, he found that individuals who belonged to aggressive peer groups reported increasing their use of homophobic epithets over time. Also, he found that the increase in the use of homophobic epithets was moderated by being in a group that held negative attitudes toward gays and lesbians. In other words, students with friends who held negative attitudes toward LGBT youth reported an increase in calling other students "gay," "faggot," or "lesbo."

To make the implications even more salient, this special series includes two commentaries from two leading scholars in the field of school psychology. Jane Conoley, Dean of the College of Education at the University of California, Santa Barbara, offers insights related to implications for school policy and teacher education training programs (Conoley, 2008). Deborah Tharinger, professor of school psychology at the University of Texas at Austin, offers commentary on practice implications for mental health practitioners and how findings can inform assessment (Tharinger, 2008). Both commentaries affirm the complexity of integrating the two literatures on bullying and homophobia.

The recent study commissioned by the GLSEN in 2005 found several important findings regarding the harassment of LGBT youth in schools (Harris Interactive \& GLSEN, $2005)$. Of the 3,450 public and private/parochial U.S. students surveyed online, astounding numbers were reported for the percentage of students who found their schools to be intolerant of sexual orientation. Thirty-three percent reported being verbally or physically harassed or assaulted during the past year as a result of their perceived or actual sexual orientation. Over $50 \%$ of the respondents frequently heard students make homophobic remarks, and $51 \%$ of the students frequently heard students make sexist remarks. Common phrases (some 69\% reporting) included "that's so gay" or "you're so gay." Students who are or are perceived to be LGBT were three times as likely as non-LGBT students to feel not safe at school (22\% vs. $7 \%$ ) and $90 \%$ of the LGBT teens had been verbally or physically harassed or assaulted during the past year because of their perceived or actual appearance, gender, sexual orientation, gender expression, race/ ethnicity, disability, or religion.

This study is also significant in that it included surveys completed by 588 gay or lesbian parents of children (kindergarten to Grade 12) and 154 middle and high school students with parents who identify as lesbian or gay. The findings of this report published in 2008 by GLSEN (Kosciw \& Diaz, 2008) further highlighted the importance of understanding the world of children and families in which parents are LGBT. Interestingly, LGBT parents experience the climate of schools similar to LGBT students in that $53 \%$ felt excluded by the school through their policies, $26 \%$ felt maltreated by other parents, and $21 \%$ heard comments from other students about LGBT. Furthermore, it appears that a tolerant school environment serves as a buffer for parents too; more specifically, parents who perceived the school had policies that protected their children felt less maltreated. Surveys of middle and high school students of LGBT parents indicated a disturbing finding in that over $25 \%$ of the students reported that teachers encouraged them not to speak of their family to other students.

Findings of the 2005 and 2008 GLSEN report provide the strongest empirical support for this special issue. It is clear that students across the life span attend classes in which being anything but heterosexual places them at risk for victimization and humiliation. In fact it appears that being anything but heterosexual equals something bad as early as elementary school. It behooves the field of school psychology to forge a research agenda in this area in order to facilitate prevention and intervention programs. This special issue represents an important first step in this direction. 


\section{References}

Conoley, J. C. (2008). Sticks and stones can break my bones and words can really hurt me. School Psychology Review, 37, 217-220.

Crick, N. R. (1996). The role of relational aggression, overt aggression, and prosocial behavior in the prediction of children's future social adjustment. Child Development, 67, 2317-2327.

Epstein, D. (2001). Boyz' own stories: masculinities and sexualities in schools. In W. Martino \& B. Meyenn (Eds.), What about the boys? Issues of masculinity in schools (pp. 96-109). Philadelphia, PA: Open University Press.

Espelage, D. L., Aragon, S. R., Birkett, M., \& Koenig, B. W. (2008). Homophobic teasing, psychological outcomes, and sexual orientation among high school students: What influence do parents and schools have? School Psychology Review, 37, 202-216.

Espelage, D. L., Bosworth, K., \& Simon, T. R. (2000). Examining the social context of bullying behaviors in early adolescence. Journal of Counseling and Development, 78(3), 326-333.

Espelage, D. L., \& Swearer, S. M. (2003). Research on bullying and victimization: What have we learned and where do we go from here? In S. M. Swearer \& D. L. Espelage (Eds.), Bullying prevention and intervention: Integrating research and evaluation findings [Special issue]. School Psychology Review, 32(3), 365-383.

Harris Interactive and GLSEN. (2005). From teasing to torment: School climate in America, a survey of students and teachers. New York: GLSEN.

Kimmel, M. S., \& Mahler, M. (2003). Adolescent masculinity, homophobia, and violence. American Behavioral Scientist, 465, 1439-1458.

Kosciw, J. G. (2004). The 2003 national school climate survey: The school-related experiences of our nation's lesbian, gay, bisexual, and transgender youth. New York: GLSEN.

Kosciw, J. G., \& Diaz, E. M. (2008). Involved, invisible, ignored: The experiences of lesbian, gay, bisexual and transgender parents and their children in our nation's $K-12$ schools. New York: GLSEN.

Pharr, S. (1988). Homophobia: A weapon of sexism. Chardon Press.
Phoenix, A., Frosh, S., \& Pattman, R. (2003). Producing contradictory masculine subject positions: Narratives of threat, homophobia, and bullying in 11-14 year old boys. Journal of Social Issues, 59, 179-195.

Plummer, D. C. (2001). The quest for modern manhood: Masculine stereotypes, peer culture and the social significance of homophobia. Journal of Adolescence, 24, 15-23.

Poteat, V. P. (2008). Contextual and moderating effects of the peer group climate on use of homophobic epithets. School Psychology Review, 37, 188-201.

Poteat, V. P., \& Espelage, D. L. (2005). Exploring the relation between bullying and homophobic verbal content: The Homophobic Content Agent Target (HCAT) Scale. Violence and Victims, 20, 513-528.

Poteat, P., Espelage, D. L., \& Green, H. (2007). The socialization of dominance: Peer group contextual effects on heterosexist and dominance attitudes. Journal of Personality and Social Psychology, 92(6), 10401050.

Rivers, I. (2001). The bullying of sexual minorities at school: Its nature and long-term correlates. Educational \& Child Psychology, 18(1), 33-46.

Rivers, I., \& Noret, N. (2008). Well-being among samesex and opposite-sex- attracted youth at school. School Psychology Review, 37, 174-187.

Stein, N. (1995). Sexual harassment in K-12 schools: The public performance of gendered violence. Harvard Educational Review, 65(2), 145-162.

Swearer, S. M., Turner, R. K., Givens, J. E., \& Pollack, W. S. (2008). "You're so gay!": Do different forms of bullying matter for adolescent males? School Psychology Review, 37, 160-173.

Tharinger, D. J. (2008). Maintaining the hegemonic masculinity through selective attachment, homophobia, and gay-baiting in schools: Challenges to intervention. School Psychology Review, 37, 221-227.

Wright, L. W., Adams, H. E., \& Bernat, J. (1999). Development and validation of the homophobia scale. Journal of Psychopathology and Behavioral Assessment, 21, 337-347.

Date Received: March 19, 2008

Date Accepted: March 25, 2008

Action Editor: Thomas Power

Dorothy L. Espelage, $\mathrm{PhD}$, is a professor and associate chair, Department of Educational Psychology, University of Illinois at Urbana-Champaign, Champaign, IL. Her research program includes investigation of bullying, sexual harassment, dating violence, and homophobic attitudes and behaviors among children and adolescents.

Susan M Swearer, $\mathrm{PhD}$, is an associate professor of school psychology at the University of Nebraska-Lincoln and the codirector of the Nebraska Internship Consortium in Professional Psychology. Her research interests center around the examination of psychological and environmental influences that contribute to bullying behavior among schoolaged youth and promoting models of data-based decision making in bullying prevention and intervention. 